\title{
A Systematic Review about Educational Interventions based on the Health Belief Model (HBM) aimed to prevent and control diabetes in Iran
}

\author{
Review Article
}

Reza Sadeghi' ${ }^{1}$ Fatemeh Baghernezhad Hesary ${ }^{2}$, Narges Khanjani ${ }^{3 *}$

\author{
1. Assistant Professor, Department of Public Health, School of Public Health, \\ Sirjan School of Medical Sciences, Sirjan, Iran. \\ 2. PhD in Health Education and Health Promotion, Social Determinates of Health Research, \\ Birjand University of Medical Sciences, Birjand, Iran. \\ 3. Professor, Neurology Research Center, Kerman University of Medical Sciences, Kerman, Iran.
}

\begin{abstract}
Background: Diabetes is one of the most common metabolic diseases in the world and a serious health problem, that requires comprehensive interventions. This systematic review was conducted to summarize educational interventions based on the Health Belief Model aimed to prevent and control diabetes. Methods: Searches were done on May 30, 2019 in PubMed, Web of Science, Google Scholar, Embase, Scopus, SID, Magiran, and IranMedex databases in English and Persian. The inclusion criteria included quantitative original interventional studies that aimed to control type 2 diabetes, and the intervention was based on the Health Belief Model. Studies done outside of Iran, interventions on other types of diabetes, non-interventional studies, and reviews were excluded. Results: Eventually, 13 studies (6 English and 7 Persian articles) entered this systematic review. The intervention durations were from 2 to 3 months. These studies fell into three broad categories: 1- Prevention of the disease 2- Improving Nutrition behaviors in patients 3-Prevention of disease complications or its progress. All of the educational interventions showed a positive effect for education on the prevention and control of diabetes. Conclusions: Interventions based on the HBM have shown an effective role in controlling and preventing diabetes.
\end{abstract}

Key Words: Systematic review, Diabetes, Health Belief Model, Intervention.

\section{Introduction}

Diabetes is a metabolic and multi factorial disorder characterized by chronic hyperglycemia, resulting from an insufficient secretion or action of insulin (1). Diabetes is referred to as an "epidemic" and is considered as a major public health problem, responsible for 9 percent of all deaths in the world (2). Diabetes type 1 and type 2 are two main forms of this chronic disease, affecting approximately $10 \%$ and $90 \%$ of the total population of diabetics (3).

Type 2 diabetes or adult diabetes includes patients who have insulin resistance, and may have insulin deficiency as well. Diabetes is associated with various disorders in the metabolism of glucose, protein, and fat. Chronic hyperglycemia causes damage to the body organs, especially the eyes, kidneys, nerves, the heart and blood vessels(4).

Diabetes is currently the fifth cause of death in Western societies and the fourth most common cause

* Corresponding Author:

Narges Khanjani,

Professor, Neurology Research Centre, Kerman

University of Medical Sciences,

Kerman, Iran.

Email - ․khanjani@kmu.ac.ir for visiting a doctor. The global prevalence of diabetes is predicted to increase from $4 \%$ in 1995 to around $5.4 \%$ in 2025 . During this time, the population of affected people will increase by $122 \%$ (5). The prevalence of diabetes in Iran in 1995, 2000, and 2025 was estimated to be $5.5,5.7$, and $6.8 \%$, respectively (6).

The direct and indirect costs of diabetes and its complications are very high compared to other diseases. This disease is increasing with industrialization and urbanization. Physical activity, type of diet, familial history, stress and some environmental and genetic factors are involved in the development of this disease (7).

Given the increasing prevalence and burden of diabetes, educational interventions based on standardized frameworks are required to control the epidemic. Proper behavioral models should be used in order to increase the efficiency of education. One of these models is the Health Belief Model (8).

The Health Belief Model considers behavior as a function of the individual's knowledge and attitude, and according to its components prompts individuals to perceive a health threat and follow healthy behaviors (9). This model was initially developed to study why people do not accept health advice and to explain why people do not see themselves at risk for acquiring diseases (10). This model is a comprehensive model that closely relates to the prevention of disease and 
Reza Sadeghi et.al., Educational Interventions based on the Health Belief Model (HBM) aimed to prevent and control diabetes

shows the relation between beliefs and behavior. The health belief model has been used to develop effective interventions to change health-related behaviors by targeting various aspects of the model's key constructs. The HealthBelief Model (HBM) constructs include perceived susceptibility, perceived severity, perceived barriers, perceived benefits, cues to action, and self efficacy (Figure 1) (3).

\section{Figure 1}

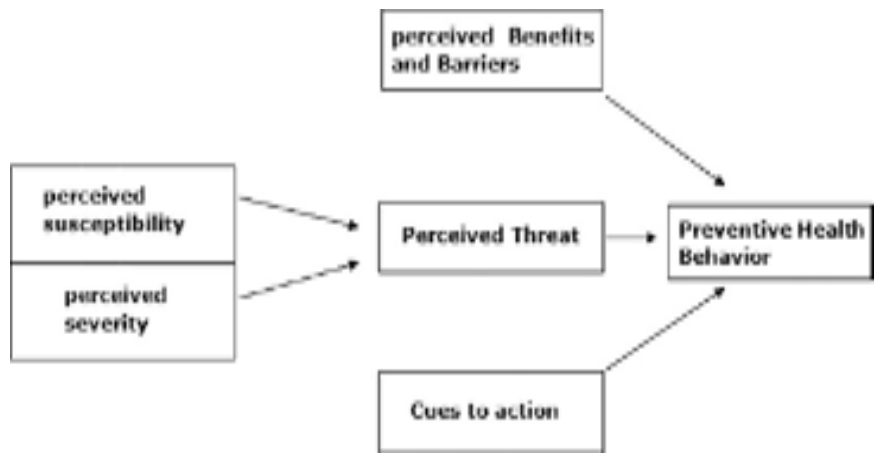

This systematic review was conducted to summarize educational interventions based on the Health Belief Model that aimed to prevent and control diabetes.

\section{Materials and Methods \\ Search strategies}

Searches were done on May 30, 2019 in PubMed, Web of Science, Google Scholar, Embase, and Scopus databases for Latin articles, and in the SID, Magiran, and Iran Medex databases for Persian articles. The search strategy has been shown in table 1 .

Table 1: The search strategy used in this review.

Diabetes OR "Type 2 diabetes" OR "Prevention and control of diabetes" OR "Metabolic disorder"

\section{AND}

Intervention OR "Health education" OR "Educational intervention" OR Effect

\section{AND}

\section{"Health Belief Model" OR HBM}

\section{Inclusion and Exclusion Criteria}

Inclusion criteria included quantitative original interventional studies that aimed to control type 2 diabetes, and the intervention was based on the Health Belief Model. Studies done outside of Iran, interventions on other types of diabetes, noninterventional studies, and reviews were excluded.

\section{Quality Assessment}

The Consolidated Standards of Reporting Trials (CONSORT) were used for appraising the studies.This checklist contains 25 questions, in which each question is given a 0 or 1 score. Studies that scored more than 15 were included and studies with a score of 15 or less were excluded (11).

\section{Extracting data}

Two referees independently reviewed the criteria for including studies, and in case of disagreement between the authors, a third referee was used.

The study information was extracted according to a standard form. This form included the names of the authors, the location of the study, year of study, purpose of the study, type of study, target group, population size, description of the intervention, and the most important results of the selected articles.

\section{Results}

After searching the aforementioned electronic databases, 4562 related articles (2417 in English and 2145 in Persian) were retrieved. A large number of articles (1957 articles) were duplicates and were deleted. From the remaining 2605 articles, 2472 were excluded because they were reviews, non-interventional studies or studies done outside of Iran. 36 article were excluded because they were about other types of diabetes, and 84 did not score enough on CONSORT. Finally, 13 studies (6 English and 7 Persian articles) entered the review (Figure 2).

Figure 2: Flowchart for selection of studies

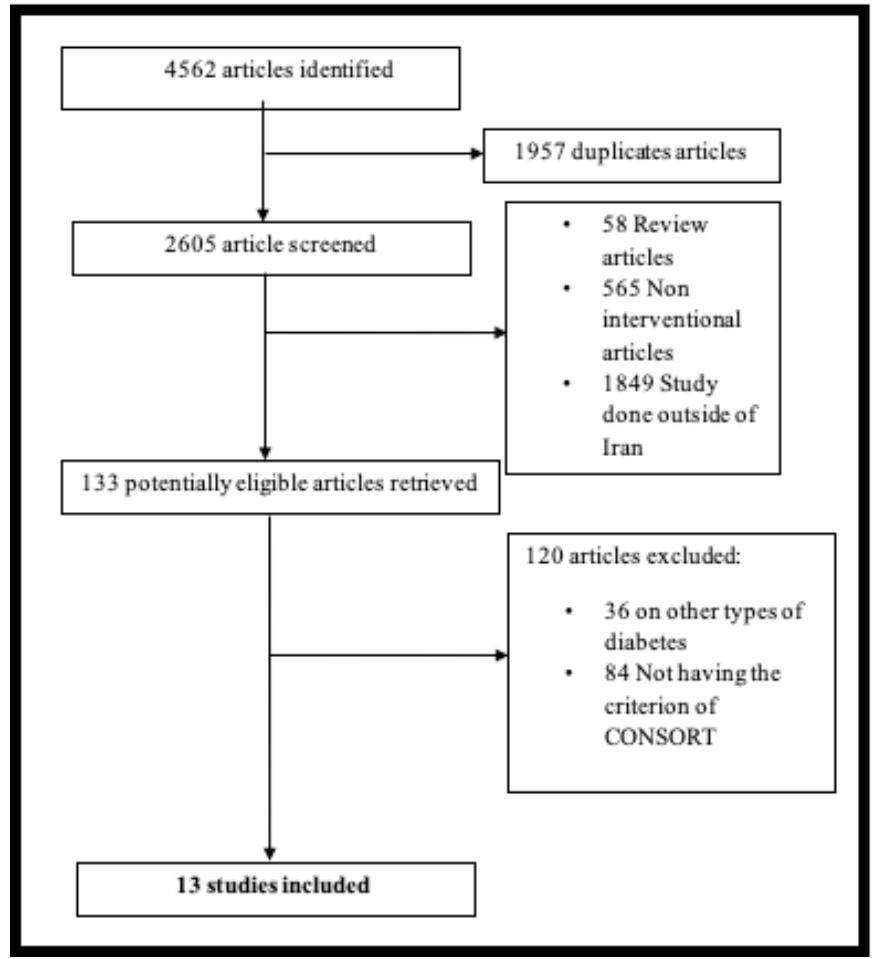

The results showed that these studies were mainly in three categories;1- Prevention of the disease (four articles) 2- Improving Nutrition Behaviors in patient (four articles) 3- Prevention of disease complications or its progress (five articles).The information extracted from the studies are summarized in table 2 . 
International Journal of Ayurvedic Medicine, Vol 11 (1), 15-22

Table 2. Summary of articles included in this review

\begin{tabular}{|c|c|c|c|c|c|}
\hline $\begin{array}{l}\text { Author / } \\
\text { year }\end{array}$ & $\begin{array}{l}\text { Place/ Study } \\
\text { population } \\
\text { and size }\end{array}$ & Study variables & $\begin{array}{l}\text { Intervention method } \\
\text { Duration of intervention }\end{array}$ & Results & $\begin{array}{l}\text { CONSORT } \\
\text { score }\end{array}$ \\
\hline $\begin{array}{l}\text { Shamsi, } \\
2009 \\
(12)\end{array}$ & $\begin{array}{l}\text { Isfahan } / 88 \\
\text { women with } \\
\text { type } 2 \\
\text { diabetes }\end{array}$ & $\begin{array}{l}\text { Health belief } \\
\text { model constructs, } \\
\text { patient } \mathrm{HbA}_{1} \mathrm{c} \\
\text { and FBS levels }\end{array}$ & $\begin{array}{l}\text { Four 60-minute training } \\
\text { sessions in the form of } \\
\text { lectures, questions and } \\
\text { answers, group } \\
\text { discussions, PowerPoint } \\
\text { presentations and practical } \\
\text { demonstration (walking } \\
\text { along with patients in } \\
\text { urban parks), along with } \\
\text { showing images of diabetic } \\
\text { patients who suffer from } \\
\text { diabetic complications } \\
\text { were done. At the end of } \\
\text { the training sessions, the } \\
\text { content was provided as a } \\
\text { booklet, pamphlet and } \\
\text { poster to patients. } \\
3 \text { months }\end{array}$ & $\begin{array}{l}\text { The mean scores of HBM } \\
\text { Model variables, i.e } \\
\text { susceptibility, severity, } \\
\text { perceived benefit and barriers, } \\
\text { significantly increased in the } \\
\text { experimental group compared } \\
\text { to controls after the } \\
\text { intervention. Also, behavioral } \\
\text { walking, rates of HbA1c } \\
\text { (before intervention 9.59\%, } \\
\text { after three months } 8.63 \% \text { ) } \\
\text { and FBS levels (before } \\
\text { intervention } 184.63 \mathrm{mg} / \mathrm{dl} \text {, } \\
\text { after three months } 151.29 \text { ) } \\
\text { improved significantly in the } \\
\text { intervention group, compared } \\
\text { to controls (p<0/001). }\end{array}$ & 20 \\
\hline $\begin{array}{l}\text { Piri, } 2010 \\
\text { (13) }\end{array}$ & $\begin{array}{l}\text { Najafabad, } \\
128 \text { diabetic } \\
\text { patients }\end{array}$ & $\begin{array}{l}\text { Health Belief } \\
\text { Model } \\
\text { constructs, and } \\
\text { diet }\end{array}$ & $\begin{array}{l}\text { The intervention was } \\
\text { undertaken in } \\
\text { four, } 40 \text { minute, weekly } \\
\text { sessions while participants } \\
\text { in both case and control } \\
\text { groups were under } \\
\text { standard treatment } \\
\text { identical to the pre- } \\
\text { intervention phase. The } \\
\text { intervention addressed } \\
\text { educational needs and } \\
\text { included some material } \\
\text { congruent with the health } \\
\text { belief model which was } \\
\text { presented via lectures and } \\
\text { pamphlets. } \\
3 \text { months }\end{array}$ & $\begin{array}{l}\text { After the intervention, } \\
\text { significant improvements } \\
\text { were seen in the intervention } \\
\text { group inperceived } \\
\text { susceptibility }(\mathrm{P}=0.001), \\
\text { perceived severity }(\mathrm{P} 70.001) \text {, } \\
\text { perceived barriers }(\mathrm{P}=0.004) \\
\text { and practice (diet obedience) } \\
(\mathrm{P}<0.001) \text {. }\end{array}$ & 18 \\
\hline $\begin{array}{l}\text { Motlagh, } \\
2012 \\
(14)\end{array}$ & $\begin{array}{l}\text { Gachsaran, } \\
140 \text { patients }\end{array}$ & $\begin{array}{l}\text { Health Belief } \\
\text { Model constructs }\end{array}$ & $\begin{array}{l}\text { Four one-hour lectures and } \\
\text { group discussions were } \\
\text { held in one month. Also, } \\
\text { two one-hour training } \\
\text { sessions were conducted } \\
\text { for the families of the } \\
\text { patients in the intervention } \\
\text { group. } \\
3 \text { months }\end{array}$ & $\begin{array}{l}\text { The results showed a } \\
\text { statistically significant } \\
\text { improvement in the } \\
\text { intervention group after the } \\
\text { implementation of } \\
\text { educational programs in the } \\
\text { mean knowledge, perceived } \\
\text { severity, perceived } \\
\text { susceptibility, perceived } \\
\text { benefits and perceived self- } \\
\text { efficacy scores; and decrease } \\
\text { in perceived barriers scores (P } \\
<0.05) \text {. }\end{array}$ & 22 \\
\hline
\end{tabular}


Reza Sadeghi et.al., Educational Interventions based on the Health Belief Model (HBM) aimed to prevent and control diabetes

\begin{tabular}{|c|c|c|c|c|c|}
\hline $\begin{array}{l}\text { Kashfi, } \\
2012 \\
(15)\end{array}$ & $\begin{array}{l}\text { Shiraz, } 100 \\
\text { type } 2 \\
\text { diabetic } \\
\text { patients }\end{array}$ & $\begin{array}{l}\text { Health Belief } \\
\text { Model constructs } \\
\text {, and fasting } \\
\text { blood sugar } \\
\text { (FBS) and } \\
\text { glycoside } \\
\text { hemoglobin } \\
\text { (HbA1c) }\end{array}$ & $\begin{array}{l}\text { The intervention was } 3 \\
\text { sessions (each } 60 \text { minutes). } \\
3 \text { months }\end{array}$ & $\begin{array}{l}\text { After the intervention, there } \\
\text { was a significant } \\
\text { improvement in the mean } \\
\text { score of the HBM model } \\
\text { variables (susceptibility, } \\
\text { severity, benefit and } \\
\text { perceived obstacles) in the } \\
\text { intervention group. } \\
\text { Additionally, behavioral } \\
\text { jogging, level of HbA1C and } \\
\text { FBS improved significantly in } \\
\text { the intervention group } \\
\text { compared to the control } \\
\text { group. }\end{array}$ & 23 \\
\hline $\begin{array}{l}\text { Sadeghi, } \\
2014 \\
(16)\end{array}$ & $\begin{array}{l}\text { Sirjan, } 80 \\
\text { people over } \\
30 \text { years old }\end{array}$ & $\begin{array}{l}\text { Knowledge, } \\
\text { Health Belief } \\
\text { Model constructs }\end{array}$ & $\begin{array}{l}\text { The intervention included } \\
\text { two sessions of training for } \\
\text { one hour in a one-month } \\
\text { interval that included } \\
\text { lecture and group } \\
\text { discussion. At the end of } \\
\text { the training sessions, the } \\
\text { content was given as a } \\
\text { booklet and pamphlet to } \\
\text { the participants. } \\
3 \text { months }\end{array}$ & $\begin{array}{l}\text { After the intervention, the } \\
\text { knowledge scores increased } \\
\text { significantly in both } \\
\text { intervention and control } \\
\text { groups, which were probably } \\
\text { due to the routine education } \\
\text { program in that center. But } \\
\text { significant increase in attitude } \\
\text { and practice was only } \\
\text { observed in the intervention } \\
\text { group. Also perceived } \\
\text { benefits, perceived barriers } \\
\text { and cues to action } \\
\text { significantly increased in the } \\
\text { intervention group compared } \\
\text { to the control group } \\
\text { (p<0.001). But, there was not } \\
\text { any significant change in the } \\
\text { control group. }\end{array}$ & 22 \\
\hline $\begin{array}{l}\text { Bayat, } \\
2013 \\
(17)\end{array}$ & $\begin{array}{l}\text { Tehran, } 120 \\
\text { patients with } \\
\text { type II } \\
\text { diabetes }\end{array}$ & $\begin{array}{l}\text { Health Belief } \\
\text { Model constructs }\end{array}$ & $\begin{array}{l}\text { The educational program } \\
\text { consisted of two } 30 \text { to } 45 \\
\text { minute sessions, presented } \\
\text { via pamphlets and face to } \\
\text { face lectures using the } \\
\text { "question and answer" } \\
\text { method. The "question and } \\
\text { answer" method was used } \\
\text { to encourage the } \\
\text { participants to get involved } \\
\text { in the process and to make } \\
\text { sure that they were paying } \\
\text { attention. Also follow up } \\
\text { phone calls were made to } \\
\text { the participants after the } \\
\text { program. } \\
3 \text { months }\end{array}$ & $\begin{array}{l}\text { The educational program had } \\
\text { a positive and significant } \\
\text { impact ( } \mathrm{p}<0.001 \text { ) on the } \\
\text { extended health model belief } \\
\text { constructs (including } \\
\text { perceived susceptibility, } \\
\text { perceived intensity, perceived } \\
\text { benefits, perceived barriers } \\
\text { and self-efficacy) in the } \\
\text { intervention group, } 3 \text { and } 6 \\
\text { months after the intervention. }\end{array}$ & 21 \\
\hline
\end{tabular}




\begin{tabular}{|c|c|c|c|c|c|}
\hline $\begin{array}{l}\text { Zareban, } \\
2013 \\
(18)\end{array}$ & $\begin{array}{l}\text { Zahedan, } 138 \\
\text { female } \\
\text { diabetics aged } \\
30 \text { to } 60 \text { years }\end{array}$ & $\begin{array}{l}\text { Health Belief } \\
\text { Model } \\
\text { constructs, self- } \\
\text { care and HbA1c }\end{array}$ & $\begin{array}{l}\text { An educational program in } \\
5 \text { sessions for one month. } \\
\text { The educational program } \\
\text { consisted of lecture, } \\
\text { question and answer, group } \\
\text { discussion and film } \\
\text { screening. } \\
3 \text { months }\end{array}$ & $\begin{array}{l}\text { The results showed that the } \\
\text { mean scores of HBM } \\
\text { structures in groups, before } \\
\text { and after the educational } \\
\text { intervention, had a } \\
\text { statistically significant } \\
\text { difference. Reduction of } \\
\text { HbA1c levels in two studied } \\
\text { groups was significant (from } \\
9.63 \mathrm{mg} / \mathrm{l} \text { before the } \\
\text { intervention to } 8.30 \mathrm{mg} / 1 \text { at } 3 \\
\text { months after training). }\end{array}$ & 22 \\
\hline $\begin{array}{l}\text { Baghiani } \\
\text { Moghada } \\
\mathrm{m}, 2014 \\
(19)\end{array}$ & $\begin{array}{l}\text { Birjand, } 88 \\
\text { patients with } \\
\text { type II } \\
\text { diabetes }\end{array}$ & $\begin{array}{l}\text { Health Belief } \\
\text { Model } \\
\text { constructs, } \\
\text { knowledge, self- } \\
\text { care behavior }\end{array}$ & $\begin{array}{l}\text { Instructional text messages } \\
\text { was sent by a bulk SMS } \\
\text { system to the intervention } \\
\text { group during one month. } \\
\text { The SMS messages } \\
\text { included } 15 \text { SMS } \\
\text { messages, sent one day in } \\
\text { between at 10:30 in the } \\
\text { morning. } \\
3 \text { months }\end{array}$ & $\begin{array}{l}\text { Before the intervention, there } \\
\text { were no significant } \\
\text { differences in demographic } \\
\text { characteristics, the mean } \\
\text { score of knowledge, self-care } \\
\text { behavior and components of } \\
\text { the HBM between two groups } \\
\text { (P }>0.05) \text {, but after the } \\
\text { intervention, the mean score } \\
\text { of these variables in the } \\
\text { experimental group } \\
\text { significantly increased } \\
(\mathrm{P}<0.01) \text {. }\end{array}$ & 20 \\
\hline $\begin{array}{l}\text { Farahani , } \\
2015 \\
(20)\end{array}$ & $\begin{array}{l}\text { Arak, } 130 \\
\text { patients with } \\
\text { diabetes }\end{array}$ & $\begin{array}{l}\text { Health Belief } \\
\text { Model constructs }\end{array}$ & $\begin{array}{l}\text { Four one-hour lecture and } \\
\text { group discussions were } \\
\text { held in } 3 \text { months. Also, the } \\
\text { content was given to the } \\
\text { participants as a booklet } \\
\text { and brochure. } \\
3 \text { months. }\end{array}$ & $\begin{array}{l}\text { After the educational } \\
\text { intervention, perceived } \\
\text { susceptibility, perceived } \\
\text { benefits, self-efficacy, internal } \\
\text { and external guidelines and } \\
\text { performance in the field of } \\
\text { medication adherence } \\
\text { increased significantly } \\
\text { (p<0.05) while perceived } \\
\text { barriers and perceived } \\
\text { severity, did not change } \\
\text { significantly (p }>0.05) \text {. }\end{array}$ & 19 \\
\hline $\begin{array}{l}\text { Zamani, } \\
2016 \\
(21)\end{array}$ & $\begin{array}{l}\text { Zarand, } 100 \\
\text { patients with } \\
\text { diabetes }\end{array}$ & $\begin{array}{l}\text { Health Belief } \\
\text { Model } \\
\text { constructs, and } \\
\text { medication } \\
\text { adherence }\end{array}$ & $\begin{array}{l}\text { Educational interventions } \\
\text { included } 4 \text { training } \\
\text { sessions of } 8-12 \text { people on } \\
\text { a weekly basis. Each } \\
\text { training session lasted for } \\
60-90 \text { minutes. } \\
3 \text { months. }\end{array}$ & $\begin{array}{l}\text { After the intervention, the } \\
\text { mean scores of perceived } \\
\text { sensitivity }(\mathrm{P}<0.001), \\
\text { perceived severity }(\mathrm{P}<0.001) \text {, } \\
\text { perceived benefits }(\mathrm{P}<0.001) \text {, } \\
\text { perceived barriers }(\mathrm{P}<0.001) \text {, } \\
\text { perceived self-efficiency } \\
(\mathrm{P}<0.0001) \text {, cue to action } \\
(\mathrm{P}<0.0001) \text {, and medication } \\
\text { adherence }(\mathrm{P}<0.0001) \\
\text { increased significantly. }\end{array}$ & 21 \\
\hline
\end{tabular}


Reza Sadeghi et.al., Educational Interventions based on the Health Belief Model (HBM) aimed to prevent and control diabetes

\begin{tabular}{|c|c|c|c|c|c|}
\hline $\begin{array}{l}\text { Fani, } 2017 \\
(22)\end{array}$ & $\begin{array}{l}\text { Tehran, with } \\
216 \text { type } 2 \\
\text { diabetes } \\
\text { patients }\end{array}$ & $\begin{array}{l}\text { Health Belief } \\
\text { Model } \\
\text { constructs, } \\
\text { nutrition } \\
\text { adherence, and } \\
\text { HbA1c }\end{array}$ & $\begin{array}{l}\text { Educational interventions } \\
\text { included } 6 \text { training } \\
\text { sessions. Also, the content } \\
\text { was given to participants } \\
\text { as a poster, pamphlet, } \\
\text { booklet and brochure. } \\
3 \text { months. }\end{array}$ & $\begin{array}{l}\text { In the intervention group, } \\
\text { there were statistically } \\
\text { significant differences } \\
\text { between all parts of HBM } \\
\text { after educational intervention } \\
\text { (perceived susceptibility ( } p \\
<0.001 \text { ), perceived severity (p } \\
<0.001 \text { ), perceived benefits ( } \mathrm{p} \\
<0.001 \text { ), perceived barriers (p } \\
<0.001 \text { ), cues to action (p } \\
<0.001 \text { )), also nutrition } \\
\text { adherence (p <0.001) and } \\
\text { HbA1c. But, there was no } \\
\text { significant change in the } \\
\text { control group after } \\
\text { intervention. }\end{array}$ & 20 \\
\hline $\begin{array}{l}\text { Porgholmi, } \\
2017 \\
(23)\end{array}$ & $\begin{array}{l}\text { Rasht, } 84 \\
\text { patients with } \\
\text { type II } \\
\text { diabetes }\end{array}$ & $\begin{array}{l}\text { Health Belief } \\
\text { Model } \\
\text { constructs, self- } \\
\text { care behavior, } \\
\text { and HbA1c }\end{array}$ & $\begin{array}{l}\text { The educational program } \\
\text { for the patients in the } \\
\text { intervention group was } \\
\text { held in six, } 30 \text { to } 45 \\
\text { minute sessions, and } \\
\text { included lectures, group } \\
\text { discussion and role playing } \\
\text { techniques along with } \\
\text { providing pamphlets, } \\
\text { posters and educational } \\
\text { films. } \\
3 \text { months. }\end{array}$ & $\begin{array}{l}\text { After the intervention, the } \\
\text { mean HbA1c in the } \\
\text { intervention group } \\
\text { significantly changed. } \\
\text { However, the mean HbA1c in } \\
\text { the control group did not } \\
\text { change significantly. The } \\
\text { average score of self-care } \\
\text { behavior in the experimental } \\
\text { group before and three } \\
\text { months after the intervention, } \\
\text { significantly increased (p= } \\
0.001 \text { ). But this difference } \\
\text { was not significant in the } \\
\text { control group. }\end{array}$ & 20 \\
\hline $\begin{array}{l}\text { Tehrani, } \\
2019 \\
(24)\end{array}$ & $\begin{array}{l}\text { Tiran and } \\
\text { Karvan } \\
\text { counties } \\
\text { (Isfahan), } 100 \\
\text { patients with } \\
\text { Type } 2 \\
\text { Diabetes }\end{array}$ & $\begin{array}{l}\text { Awareness, } \\
\text { Health Belief } \\
\text { Model } \\
\text { constructs, and } \\
\text { blood glucose }\end{array}$ & $\begin{array}{l}\text { Within a month, four } \\
\text { lecture sessions, questions } \\
\text { and answers were } \\
\text { conducted using video } \\
\text { projector and PowerPoints. } \\
3 \text { months. }\end{array}$ & $\begin{array}{l}\text { After the intervention, a } \\
\text { significant improvement was } \\
\text { seen in the intervention group } \\
\text { in terms of awareness, } \\
\text { perceived susceptibility, } \\
\text { perceived severity, perceived } \\
\text { benefits, perceived barriers, } \\
\text { self-efficacy and eating } \\
\text { behavior }(\mathrm{P}<0.05) \text {. The mean } \\
\text { of blood glucose in the } \\
\text { experimental group was } \\
\text { significantly lower after the } \\
\text { educational intervention } \\
\text { compared to pre-intervention } \\
(\mathrm{P}<0.05) \text {. }\end{array}$ & 21 \\
\hline
\end{tabular}

\section{Discussion}

Diabetes is a disease that can be prevented and controlled by improving knowledge, attitude and practice, especially through education (25). The Health Belief Model (HBM) is a good framework for these interventions (26). This systematic review was conducted to investigate the effect of educational interventions based on the Health Belief Model in the prevention and control of diabetes.
In the first category of our included studies, prevention of the disease was the most important goal. Type 2 diabetes is a preventable disease that can be prevented by appropriate interventions to change lifestyle (27). Given the high prevalence of diabetes in developing countries, the primary prevention of diabetes is of particular importance especially in Iran. Identifying the risk factors of type 2 diabetes and identifying appropriate strategies for reducing the incidence of diabetes in the society is now the focus of attention of many researchers and health educators (28). 
Genetic predisposition (family history), insulin resistance, obesity, glucose tolerance, gestational diabetes mellitus, physical inactivity and inappropriate diet are among the most important contributing factors, although other factors may also be effective (29). Therefore, preventive interventions are very useful in this regard. Studies by Marion et al. show interventions such as regular physical activity and behavioral interventions help improve lifestyle and prevent diabetes (30). Lindström et al. showed that adherence to lifestyle changes after the intervention and during the follow up period led to greater risk reduction for diabetic patients (31).

The second part of our included studies, were studies in which improving nutrition behaviors among patient was their most important goal. Training on the importance of dieting among patients with diabetes can be helpful in promoting their nutritional knowledge, and observing the principles of proper nutrition is one of the most important factors in preventing the complications of diabetes (32). Sharifirad et al., considered nutrition education for diabetic patients as a necessity (33). Also, food choices in individual's have a direct effect on their energy balance, body weight, lipid levels and blood pressure (34) and by conducting nutritional interventions and ongoing support for behavior changes, health care professionals can improve their patients' health (35).The results of Tehrani et al.'s study indicated the positive effectives of correctly implemented educational interventions based on the health belief model on nutritional behaviors in type 2 diabetic patients (24).

In the third part of the included studies, prevention of disease complications or its progress were the most important goal. Diabetes and its complications can cause significant morbidity, mortality, and economic costs. Therefore, the prevention of its complications is very important, as these complications can lead to death (1). In the study of Rezaei et al., the knowledge and practice of diabetic patients increased after training, and their diabetes management improved (36). The study by Sharifirad et al showed the effect of Health Belief Model on Foot Care in Diabetic Patients with Type 2 Diabetes and showed that training was very effective on controlling diabetic wounds (37).

However, it seems that in these studies, patients were not followed up sufficiently, and in order to track the impact of educational interventions, there is a need for longer follow-ups, for at least 6 months. Therefore, future studies should do longer follow-ups to examine the impact of educational interventions and its outcomes.

\section{Conclusion}

Designed interventions based on the HBM have shown to be effective in controlling and preventing diabetes.

\section{Conflict of interest: None.}

\section{References}

1. Moosazadeh M, Asemi Z, Lankarani KB, Tabrizi R, Maharlouei N, Naghibzadeh-Tahami A, et al. Family history of diabetes and the risk of gestational diabetes mellitus in Iran: a systematic review and meta-analysis. Diabetes \& Metabolic Syndrome: Clinical Research \& Reviews. 2017;11:S99-S104.

2. Gupta A, Gupta V. Metabolic syndrome: what are the risks for humans? BioScience Trends. 2010;4(5).

3. Green EC, Murphy E. Health belief model. The Wiley Blackwell encyclopedia of health, illness, behavior, and society. 2014:766-9.

4. Balhara YPS. Diabetes and psychiatric disorders. Indian journal of endocrinology and metabolism. 2011;15(4):274.

5. Mazloomy S, Rezaeian M, NaghibzadehTahami A, Sadeghi R. Association between Health-Related Quality of Life and Glycemic Control in Type 2 Diabetics of Sirjan City in 2015. Journal of Rafsanjan University of Medical Sciences. 2017;16(1):73-82.

6. Larijani B, Abolhasani F, Mohajeri-Tehrani MR, Tabtabaie O. Prevalence of diabetes mellitus in Iran in 2000. Iranian Journal of Diabetes and Metabolism. 2005;4(3):75-83.

7. Hex N, Bartlett C, Wright D, Taylor M, Varley D. Estimating the current and future costs of Type 1 and Type 2 diabetes in the UK, including direct health costs and indirect societal and productivity costs. Diabetic Medicine. 2012;29(7):855-62.

8. Sadeghi R, Hashemi M, Khanjani N. The impact of educational intervention based on the health belief model on observing standard precautions among emergency center nurses in Sirjan, Iran. Health education research. 2018;33(4):327-35.

9. Champion VL, Skinner CS. The health belief model. Health behavior and health education: Theory, research, and practice. 2008;4:45-65.

10.Abraham C, Sheeran P. The health belief model. Predicting health behaviour. 2005;2:28-80.

11. Schulz KF, Altman DG, Moher D. CONSORT 2010 statement: updated guidelines for reporting parallel group randomised trials. BMC medicine. 2010;8(1):18.

12.Shamsi M, Sharifirad G, Kachoyee A, Hassanzadeh A. The effect of educational program walking based on health belief model on control sugar in woman by type 2 diabetics. Iranian Journal of Endocrinology and Metabolism. 2009;11(5):490-597.

13.Piri A. Effects of education based on health belief model on dietary adherence in diabetic patients. Journal of Diabetes and Metabolic Disorders. 2010;9:15.

14.Zinat MF, Sharifirad G, Jalilian F, Mirzaei AM, Aghaei A, Ahmadi JT. Effectiveness of educational programs to promote nutritional knowledge in type II diabetes patients based on health belief model. Health System Research. 2013: 9(4): 412-420.

15.Kashfi S, Jeihooni AK, Rezaianzadeh A, Amini S. The effect of health belief model educational program and jogging on control of sugar in type 2 
diabetic patients. Iranian Red Crescent Medical Journal. 2012;14(7):442.

16. Sadeghi R, Rezaeian M, Khanjani N, Iranpour A. The applied of health belief model in knowledge, attitude and practice in people referred for diabetes screening program: an educational trial. Journal of Rafsanjan University of Medical Sciences. 2015;13(11):1061-72.

17.Bayat F, Shojaeezadeh D, Baikpour M, Heshmat R, Baikpour M, Hosseini M. The effects of education based on extended health belief model in type 2 diabetic patients: a randomized controlled trial. Journal of diabetes \& Metabolic disorders. 2013;12(1):45.

18.Zareban I, Niknami S, Hiedarnia AR, Rakhshani F, Sharakipour M, Moshki M. The effect of education based on health belief model on reduction of HbA1c level in diabetes type 2. Journal of Research and Health. 2013;3(2):370-8.

19.Baghiani Moghadam M.H., Taheri G, Fallahzadeh $\mathrm{H}$, Parsa $\mathrm{M}$. The effect of instructional designed SMS based on Health Belief Model (HBM) on adoption of self-care behavior of patients with type II diabetes. Modern Care Journal 2014; 11(1): 10-18.

20.Farahani DF, Shamsi M, Khorsandi M, Ranjbaran M, Rezvanfar M. Evaluation of the effects of education based on health belief model on medication adherence in diabetic patients. Iranian Journal of Endocrinology and Metabolism. 2016; 18 (2): 83-89.

21.Zamani N, Ahmadi Tabatabaei SV, Khanjani N, Fadakar Davarani MM. The Effect of Educational Intervention Based on the Health Belief Model on Medication Adherence among Patients with Diabetes Referred to a Diabetes Center in Zarand, Kerman. Journal of Health and Development. 2017;6(2):97-109.

22.Fani N, Mohebbi B, Sadeghi R, Tol A, Shamshiri A. Assessing The Effect of Educational Intervention on Promoting Nutrition Adherence Among Patients With Type 2 Diabetes Referee to South Health Center of Tehran University of Medical Sciences: Application of Health Belief Model. Iranian Journal of Diabetes and Metabolism. 2018;17(1):13-22.

23.Porgholmi M, Farmanbar R, Kasmaei P, Omidi S. The Effect of Training Program Based on Health Belief Model Developed by the Fear of Self-Care Behavior and Hba1c Levels in Patients with Type 2 Diabetes. Iranian Journal of Health Education and Health Promotion. 2017;5(1):65-72.

24.Sa J. The Effect of an Educational Intervention Based on Health Belief Model on Nutritional Behaviors in Type 2 Diabetics. Military Caring Sciences Journal. 2019;5(4):313-9.

25.Ley SH, Hamdy O, Mohan V, Hu FB. Prevention and management of type 2 diabetes: dietary components and nutritional strategies. The Lancet. 2014;383(9933):1999-2007.
26. Hashemi M, Sadeghi R, Shamsi M. An investigation of Educational Intervention impact on pregnant women for promote preventive behaviors of influenza H1N1: using health belief model. Koomesh. 2017;19(3).

27. Association AD. Standards of medical care in diabetes - 2015 abridged for primary care providers. Clinical diabetes: a publication of the American Diabetes Association. 2015;33(2):97.

28. Shaw JE, Sicree RA, Zimmet PZ. Global estimates of the prevalence of diabetes for 2010 and 2030 . Diabetes research and clinical practice. 2010;87(1):4-14.

29. Razavian N, Blecker S, Schmidt AM, SmithMcLallen A, Nigam S, Sontag D. Population-level prediction of type 2 diabetes from claims data and analysis of risk factors. Big Data. 2015;3(4):277-87.

30.Franz MJ, Powers MA, Leontos C, Holzmeister LA, Kulkarni K, Monk A, et al. The evidence for medical nutrition therapy for type 1 and type 2 diabetes in adults. Journal of the American Dietetic Association. 2010;110(12):1852-89.

31.Lindström J, Peltonen M, Eriksson J, Ilanne-Parikka $\mathrm{P}$, Aunola S, Keinänen-Kiukaanniemi $\mathrm{S}$, et al. Improved lifestyle and decreased diabetes risk over 13 years: long-term follow-up of the randomised Finnish Diabetes Prevention Study (DPS). Diabetologia. 2013;56(2):284-93.

32.Evert AB, Boucher JL, Cypress M, Dunbar SA, Franz MJ, Mayer-Davis EJ, et al. Nutrition therapy recommendations for the management of adults with diabetes. Diabetes care. 2014;37(Supplement 1):S120-S43.

33. Sharifirad G, Entezari M, Kamran A, Azadbakht L. Efficacy of nutrition education to diabetic patient: application of health belief model. J Diabetes \& Metab Disorder. 2008;7:379-86.

34.Al-Sinani M, Min Y, Ghebremeskel K, Qazaq HS. Effectiveness of and adherence to dietary and lifestyle counselling: effect on metabolic control in type 2 diabetic Omani patients. Sultan Qaboos University Medical Journal. 2010;10(3):341.

35. Group DS. Training in flexible, intensive insulin management to enable dietary freedom in people with type 1 diabetes: dose adjustment for normal eating (DAFNE) randomised controlled trial. BMJ: British medical journal. 2002;325(7367):746.

36. Rezaei N, Tahbaz F, Kimyagar M, AlaviMajd H. The effect of nutrition education on knowledge, attitude and practice of type 1 diabetic patients from Aligoodarz. Journal of Shahrekord Uuniversity of Medical Sciences. J Shahrekord Univ Med Sci 2006, 8(2): 52-59.

37. Sharifirad GR, Mohebi S, Matlabi M. Survey of the feet care based on Health Belief Model in diabetes type II patients referring to the Diabetes research center of Kermanshah in 2006. J Birjand Univ Med Sci. 2008, 15(4): 84-90. 